\title{
SEISMIK FASIES MODELLING PADA RESERVOAR GAS BIOGENIK: STUDI KASUS PADA LAPANGAN "TG”
}

\author{
Ismail Zaky Alfatih ${ }^{1)}$, Dwa Desa Warnana ${ }^{1)}$, dan Priatin Hadi Wijaya ${ }^{2)}$ \\ ${ }^{1}$ Teknik Geofisika, Fakultas Teknik Sipil dan Perencanaan, Institut Teknologi Sepuluh Nopember \\ ${ }^{2}$ Pusat Penelitian dan Pengembangan Geologi Kelautan (P3GL), Kementrian Energi dan Sumber Daya Mineral \\ (ESDM) \\ Ismailzaki50@gmail.com
}

\begin{abstract}
Abstrak. Gas Biogenik merupakan gas dangkal yang terbentuk pada ekosistem lautan dangkal. Lapangan "TG" diketahui memiliki reservoir yang berisi fluida berupa gas biogenik yang terdapat pada reservoir limestone globigerina. Maka dari itu, perlu dilakukan seismik fasies modelling pada reservoir tersebut untuk mengetahui persebaran lateral dari properti dan fasiesnya. Metode yang digunakan ialah penggabungan dua kontrol, yaitu vertikal dan horizontal agar didapat persebaran lateral dari fasies tersebut. Kontrol vertikal berupa analisa data well untuk mengetahui jenis batuan yang ada dan melakukan pengklasifikasian berdasarkan log sonic dan densitas. Kontrol horizontal berupa grid model seismik dan seismik atribut Instantaneous Frequency. Kemudian dilakukan crossplot antara kedua kontrol tersebut sehingga didapat nilai error 0.153695 dan nilai cross-correlation sebesar -0.12558 . Lalu dilakukan modeling menggunakan grid model dengan parameter seismik atribut tersebut dan pengelompokan fasies dari data well sehingga didapat bentukan body geologi 3D antiklin dari reservoir karbonat dan didapat persebaran lateral porositas, densitas dan gelombang-p serta persebaran empat jenis pengelompokan fasies limestone globigerina.
\end{abstract}

Kata Kunci: Seismik, Well Log, Gas Biogenik, Limestone, Fasies, Properti, 3D Model, Globigerina, Reservoir

\begin{abstract}
Biogenic gas is a shallow gas that is formed on the shallow marine ecosystems. "TG" Field is known to have a globigerina limestone reservoir that containing biogenic gas fluid. Therefore, it is necessary to do seismic facies modelling in the reservoir to determine the lateral distribution of its property and its facies. The method used two controls, vertical and horizontal to obtain lateral distribution of the facies. Well log data analysis based on sonic and density log to determine the type of the rock as a vertical control. Seismic grid model and seismic attribute Instantaneous Frequency as a horizontal control. Crossplot between these two controls in order to get the error value 0.153695 and the cross-correlation value -0.12558. Then do modelling a grid model with the parameters of the seismic attributes and well data facies grouping in order to get the $3 D$ geological anticline body of carbonate reservoir and lateral distribution of porosity, density, $p$-waves and distribution of four groupings globigerina limestone facies.
\end{abstract}

Keywords: Seismic, Well Log, Biogenic Gas, Limestone, Facies, Property, 3D Model, Globigerina, Reservoir

\section{PENDAHULUAN}

Gas biogenik dihasilkan pada suhu rendah oleh dekomposisi bahan organic pada mikroorganisme anaerob (Rice and Claypool, 1981). Kenyataan bahwa biogenik memproduksi metana merupakan fenomena di alam yang tersebar luas dan biogenik sendiri ada pada lingkungan sedimen danau, sedimen laut, rawa garam, dll. Gas biogenik sendiri ditandai oleh tingginya tingkat metana (lebih dari
98\%) dan rendahnya tingkat hidrokarbon (1-2\%) dengan beberapa $\mathrm{CO} 2$ dan N2 dan lebih dari $20 \%$ cadangan gas dunia yang telah ditemukan merupakan gas biogenik (Ni dan Day, 2012).

Peneliti - peneliti China sebagai salah satu negara terdepan yang melakukan penelitian mengenai gas biogenik menjelaskan bahwa gas biogenik sendiri memiliki banyak keuntungan, yaitu perseberannya yang luas, berada pada kedalaman 
yang dangkal, eksplorasi dan pengembangannya memiliki biaya yang rendah sehingga menarik untuk perkembangan industri di China itu sendiri (Ni dan Day, 2012).

Demi melakukan perkembangan industri, utamanya dibidang migas di Jawa Timur, maka penelitian mengenai persebaran migas telah dilakukan dan hal ini menunjukkan bahwa telah terdapat beberapa lapangan gas biogenik di cekungan Jawa Timur. Shale dan coal dari zaman Meiosen hingga Pleistosen pada Tawun-Mundu Trend merupakan salah satu penghasil gas biogenik terbesar di Jawa Timur (Satyana, 2003).

Sebagai kelanjutan dari penelitian tersebut, pemodelan fasies merupakan salah satu penelitian yang bisa dilakukan. Geologi dan geofisika tidak dapat dipisahkan dalam melakukan studi awal pemodelan fasies pada lapangan gas biogenik. Salah satu studi yang dilakukan untuk pemodelan fasies adalah analisis petrofisika, analisis facies, analisis distribusi lapisan dan pemodelan fasies menggunakan data seismic dan well.

\section{TINJAUAN PUSTAKA}

\section{Geologi Regional}

Berdasarkan penelitian dari Van Bemmelen (1949), stratigrafi paling tua yang terdapat di Paparan Sunda adalah Paleozoik yang terdiri atas schists kristalin yang tidak diketahui umurnya merupakan produk pengendapan dari deposit sedimen yang telah teralterasi oleh kegiatan metamorphism regional. Baumann (1982) menyadari bahwa terdapat lima siklus sedimentasi yang terjadi di Sumatra dan Jawa pada Era Cenozoik. Setiap siklus ini dimulai dengan transgresi dan berakhir dengan fase vulkanik dan tektonik yang berlangsung sejak 10 juta tahun yang lalu setiap siklusnya, Berikut adalah gambar yang menjelaskan mengenai proses paleogeografiknya (Baumann,1982 opcite Susilohadi, 1995)

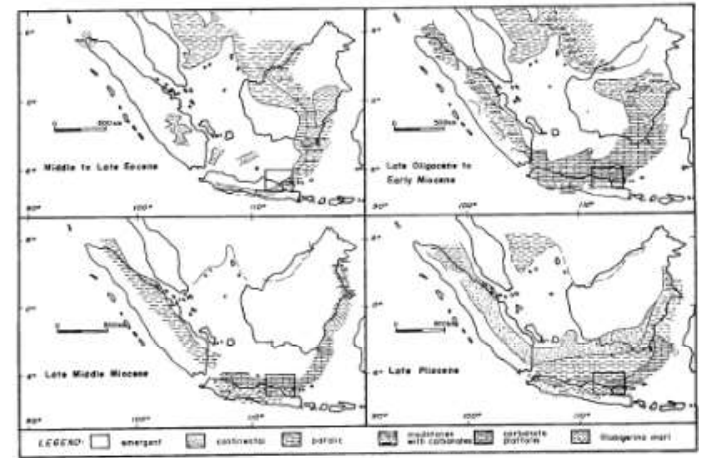

Gambar 1 Evolusi paleogeografik dari daerah barat Jawa

Pada gambar diatas dapat dilihat bahwa sedimentasi banyak terjadi pada bagian lingkar (rim) Paparan Sunda dimana gangguan tektonik seperti volcanism lebih dominan. Inti dari dataran Sunda ini menjadi sumber yang stabil untuk menjadi sedimen pengisi cekungan, dengan tambahan busur volkanik.

Litologi yang paling tersebar luas di bagian selatan Dataran Sunda adalah batukapur dengan karang (reefal limestone) berumur Miosen Awal. Deposit ini kemudian diikuti oleh fase regresif selama mudstone disepositkan pada bagian dalam dari sebelah barat Cekungan Laut Jawa. Fase regresif ini berasosiasi dengan uplift dan folding (Ben-Avraham \& Emery,1973). Selama PlioPleistosen, sedimentasi laut berlangsung di Dataran Sunda dan secara bertahap merubah morfologi cekungan menjadi daratan yang datar. Aktivitas magmatic pada Dataran Sunda berlangsung selama Era Tersier dan Kuarter. Vulkanisme terjadi sepanjang lingkar Dataran Sunda dan berasosiasi dengan kejadian tektonik major. (Van Bemmelen,1949 opcite Susilohadi, 1995)

Dari penjelasan diatas, dapat disimpulkan bahwa Cekungan Jawa Timur yang berada di Dataran Sunda termasuk ke dalam tipe cekungan back-arc/ retro-arc. Tipe dari cekungan ini adalah memilki akumulasi sedimen yang tebal khususnya yang mengarah kepada busur. Selain itu, penyebab utama terbentuknya cekungan ini adalah tumbukan antara lempeng Eurasia dan Indo-Australia yang menyebabkan terjadinya deformasi struktur di sekitar cekungan. Struktur ini mengontrol sedimentasi pada Era Tersier dan Kuarter dengan struktur yang paling menonjol adalah depresi 
berarah Barat-Timur yang sejajar dengan garis tengah Jawad an graben berarah NE-SW pada Laut Jawad an Kalimantan. Pada Jawa Timur, terdapat depresi yang berarah timur-barat yang mengandung zona antiklonorium yaitu Zona Rembang dan Kendeng. (Susilohadi, 1995)

\section{Konsep Dasar Analisa Petrofisika}

Pada Analisa Petrofisika dilakukan beberapa perhitungan nilai log untuk menentukan litologi, jenis batuan, porositas, permaebilitas, serta fluida pengisi pori tersebut.

Log gamma ray (GR) merupakan salah satu aplikasi dari log radioaktif. Prinsip dasar log gamma ray yaitu melakukan pengukuran tingkat radioaktivitas alami bumi. Log gamma ray berfungsi untuk mendeskripsikan suatu batuan yang berpotensi sebagai reservoar atau tidak serta memisahkan batuan permeabel dan shale yang impermeabel. Unsur radioaktif pada umumnya banyak berada pada shale (serpih), sedangkan pada sandstone, limestone, dan dolomit sangat sedikit jumlahnya kecuali pada batuan tersebut terendapkan mineral-mineral yang mengandung unsur radioaktif. Sehingga log ini sangat efektif digunakan untuk melakukan evaluasi formasi pada lingkungan pengendapan fluvial deltaic yang sistem perlapisannya terdiri dari sandstone atau shale (Zain, 2012). Contoh log gamma ray terdapat pada gambar di bawah.
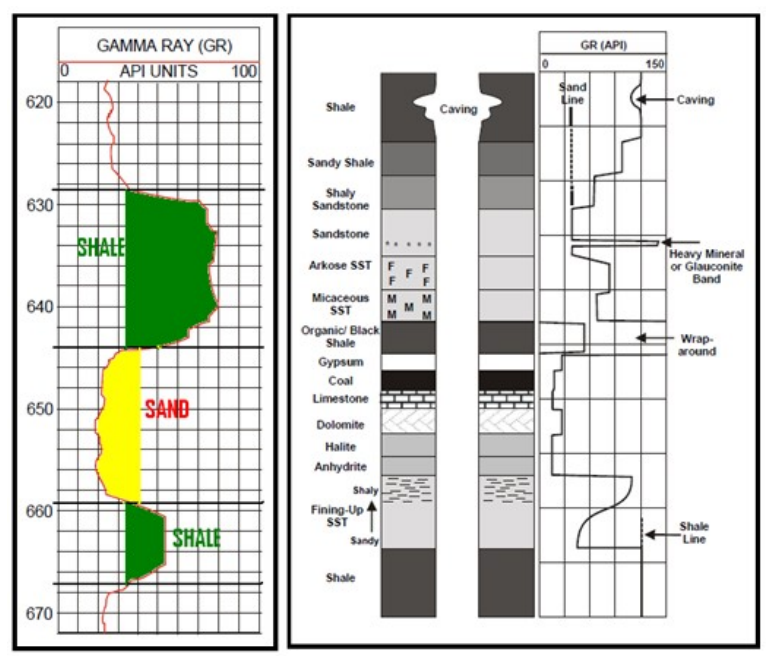

Gambar 2 Contoh Analisa Log Gamma Ray Efek Perbedaan Litologi (Glover, 2007)
Log densitas merupakan salah satu satu log porositas. Prinsip kerja log densitas ini dengan memanfaatkan teori fotolistrik menggunakan sumber radioaktif berupa gamma ray. Sinar gamma ray sebagai foton dipancarkan ke dalam formasi kemudian menumbuk elektron. Semula energi foton cukup besar, saat menumbuk elektron, energi tersebut berkurang karena diserap oleh elektron tersebut untuk melepaskan diri menjadi elektron bebas. Energi yang tersisa membuat foton terus menumbuk elektron lain dalam proses yang sama. Oleh karena itu elektron bebas akan semakin banyak dan elektron-elektron tersebut terdeteksi oleh alat densitas. Jumlah elektron yang diserap detektor secara tidak langsung menunjukkan besarnya densitas formasi. (Zain, 2012)

Tanggapan log densitas berupa densitas bulk atau densitas keseluruhan formasi termasuk matriks, fluida, atau mineral yang terkandung di dalamnya. Untuk mendapatkan nilai porositas, nilai densitas bulk harus dikonversi ke dalam porositas untuk mengetahui kondisi litologi dan keberadaan fluida.

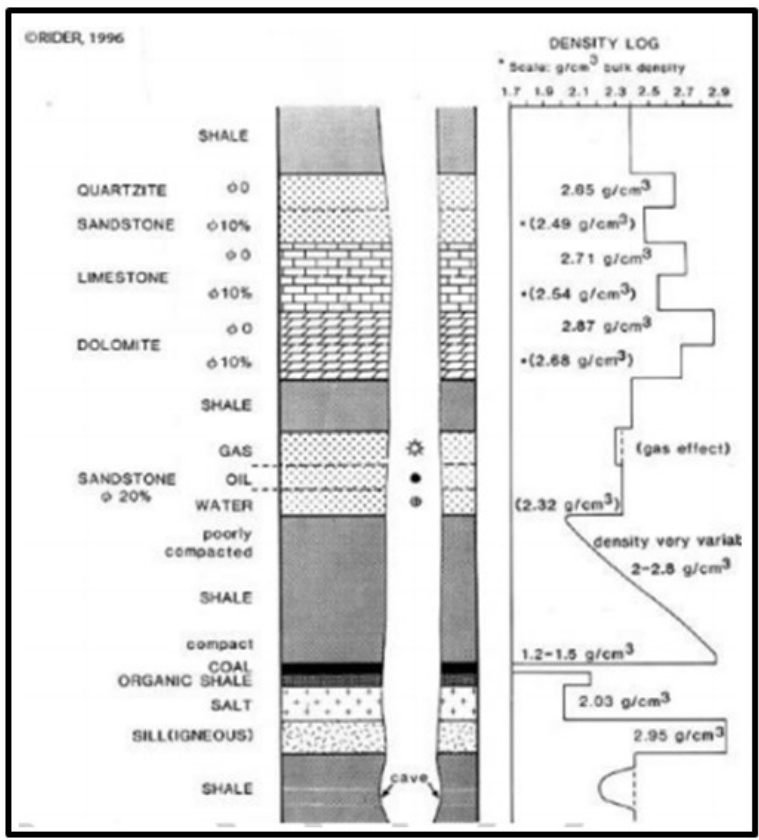

Gambar 3 Respon Log Densitas di Berbagai Litologi (Glover, 2007) 


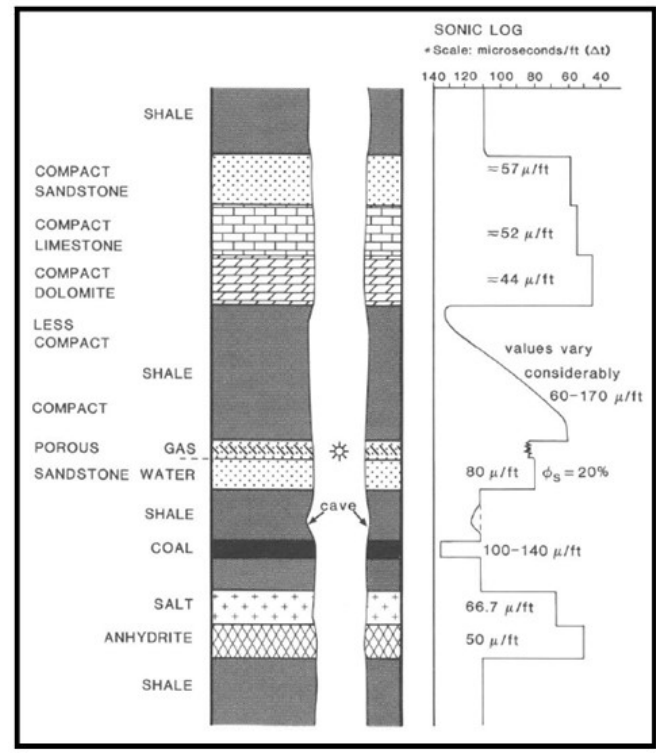

Gambar 4 Respon Log Sonik di Tiap Litologi (Glover, 2007)

Log sonic merupakan log porositas yang mengukur waktu tempuh (travel time) gelombang akustik di dalam formasi batuan pada jarak tertentu. Selain mencari porositas batuan dan identifikasi batuan, log sonik berguna sebagai informasi utama korelasi dan kalibrasi data log dengan seismik. Dalam proses well-seismic tie dibutuhkan data sonik sebagai fungsi dari impedansi akustik yang kemudian digunakan untuk pembuatan sintetik seismogram. Log sonik ini memiliki besaran $\mu \mathrm{s} / \mathrm{ft}$ atau $\mu \mathrm{s} / \mathrm{m}$ dengan skala 140-40 $\mu \mathrm{s} / \mathrm{ft}$ (Zain, 2012).

\section{Perhitungan Properti Reservoir}

Shale atau lempung merupakan salah satu batuan paling penting di dalam analisis log. Selain efek porositas dan permeabelitasnya, shale mempunyai sifat kelistrikan tersendiri yang memberikan pengaruh besar pada penentuan saturasi fluida (Schlumberger,1989). Secara praktis, perhitungan kandungan shale diasumsikan sama dengan indeks gamma ray (IGR). Indeks gamma ray didapat melalui perhitungan:

\section{Error! Reference source not found.}

dimana :

$$
G R_{\text {log }} \quad \text { = pembacaan log }
$$
gamma ray pada kedalaman formasi.

$$
\begin{aligned}
& \text { GR } R_{\min }=\text { pembacaan } \\
& \text { minimum log gamma ray (umumnya pada } \\
& \text { formasi bersih) } \\
& \text { GR } R_{\max }=\text { pembacaan maksimum } \\
& \text { log gamma ray (umumnya pada formasi } \\
& \text { lempung) }
\end{aligned}
$$

Hubungan antara densitas batuan sebenarnya dengan porositas dan lithology batuan dapat dinyatakan dalam persamaan berikut:

$$
\Phi_{D}=\frac{\rho_{m a}-\rho_{b}}{\rho_{m a}-\rho_{f}}
$$

dimana:

Error! Reference source not found. : Densitas matrik batuan, gr/cc

Error! Reference source not found.

Densitas batuan (dari hasil

pembacaan log), gr/cc

\section{Error! Reference source not found.}

Densitas fluida rata-rata, gr/cc (1

untuk fresh water, 1.1 untuk salt

water)

Error! Reference source not found.

Porositas dari density log

Dan untuk menghitung porositas sonic dari pembacaan log $\Delta \mathrm{t}$ harus terdapat hubungan antara transit time dengan porositas. Wyllie mengajukan persamaan waktu rata-rata yang merupakan hubungan linier antara waktu dan porositas (Harsono, 1997). Persamaan tersebut dapat dilihat dibawah ini:

$$
\Phi_{s}=\frac{\Delta t_{\log }-\Delta t_{\mathrm{ma}}}{\Delta t_{f}-\Delta t_{\mathrm{ma}}}
$$

dimana:

Error! Reference source not found. : Transite time yang dibaca dari log, Error!

Reference source not found.sec/ft

Error! Reference source not found. Transite time fluida, Error! Reference source not found.sec/ft (189

Error! Reference source not found.sec/ft untuk air dengan kecepatan $5300 \mathrm{ft} / \mathrm{sec}$ )

Error! Reference source not found. : Transite time matriks batuan, Error!

Reference source not found.sec/ft 
Error! Reference source not found.

Porositas dari sonic log

\section{Seismik Fasies}

Fasies adalah bodi batuan yang merupakan karakter dari kombinasi litologi, fisik dan biologis yang menunjukkan aspek yang berbeda dari bodi bagian atas, bawah, maupun secara lateral yang berdekatan. (Walker, 2006)

Hidrokarbon (minyak dan gas) terdapat di dalam batuan sediment yang terbentuk dalam berbagai lingkungan pengendapan seperti channel sungai, sistem delta, kipas bawah laut (submarine fan), carbonate mound, dan reef. Batuan sedimen yang terbentuk pada berbagai lingkungan pengendapan tersebut dikenal dengan benda geologi.

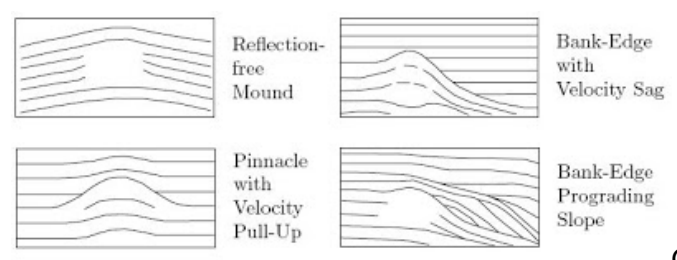

mbar 5 Tekstur Karbonat (Ensiklopediseismik, 2008)

Gelombang seismik yang menembus dan terefleksikan kembali ke permukaan akan memberikan gambaran bentuk eksternal dan tekstur internal dari benda-benda geologi tersebut. Analisis bentuk eksternal dan tekstur internal benda geologi dari penampang rekaman seismik dikenal dengan analisa fasies seismik atau seismic facies analysis.

\section{Seismik Refleksi}

Salah satu sifat akustik yang khas pada batuan adalah impedansi akustik (IA) yang merupakan hasil perkalian antara densitas media rambat $(\rho)$ dan kecepatan media rambat (V), dinyatakan dalam persamaan di bawah.

$$
I A=\rho . V
$$

Dalam mengontrol harga $I A$, kecepatan mempunyai arti yang lebih penting daripada densitas. Sebagai contoh, porositas atau material pengisi pori batuan (air, minyak, gas) lebih mempengaruhi harga kecepatan daripada densitas. Sukmono, (2007) menganalogikan IA dengan acoustic hardness. Batuan yang keras ("hard rock") dan sukar dimampatkan, seperti batu gamping mempunyai IA yang tinggi, sedangkan batuan yang lunak seperti lempung yang lebih mudah dimampatkan mempunyai IA rendah.

Penjalaran gelombang seismik di dalam bumi dapat dijelaskan dengan prinsip Huygens yang mengatakan bahwa setiap titik pada muka gelombang merupakan sumber dari gelombang baru yang menjalar dalam bentuk bola. "Setiap titik pada muka gelombang merupakan sumber bagi gelombang baru". Prinsip Huygens mengungkapkan sebuah mekanisme dimana sebuah pulsa seismik akan kehilangan energi dengan bertambahnya kedalaman.

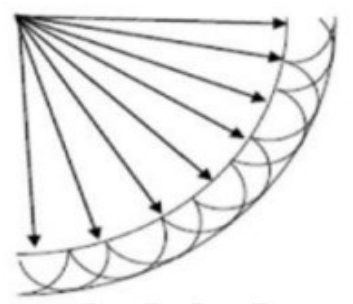

Gambar 6 Prinsip Huygens pada Gelombang Seismik

Gelombang yang terpantul akan mengikuti hukum pemantulan gelombang, yaitu hukum Snellius "Gelombang akan dipantulkan atau dibiaskan pada bidang batas antara dua medium". Menurut persamaan:

\section{Error! Reference source not found.}

\section{Atribut Instantaneous Frekuensi}

Instantaneous Frequency merupakan turunan fasa terhadap waktu (dt). Frekuensi Sesaat memiliki rentang frekuensi dari (-) Frekuensi Nyquist sampai (+) Frekuensi Nyquist, tetapi sebagian besar Frekuensi Sesaat bernilai positif.

Frekuensi Sesaat memberikan informasi tentang perilaku gelombang seismik yang mempengaruhi perubahan frekuensi seperti efek absorbsi, rekahan, dan ketebalan sistem 
pengendapan. Atenuasi gelombang seismik ketika melewati reservoir gas dapat dideteksi sebagai penurunan frekuensi, fenomena ini lebih dikenal dengan 'low frequency shadow'. Hilangnya frekuensi tinggi menunjukkan daerah overpressure

$$
\omega(t)=\frac{d q(t)}{d t}
$$

dimana:

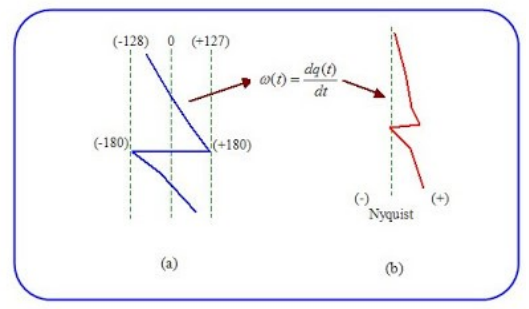

Gambar 7 (b) Frequensi Sesaat (a) sebagai turunan pertama Fasa Sesaat (Ensiklopediseismik, 2008)

\section{METODOLOGI PENELITIAN}

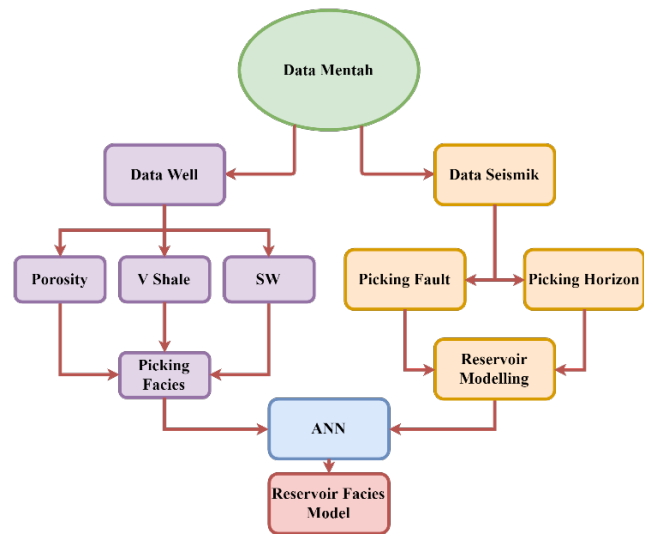

Gambar 8 Diagram Alir Pengolahan Data dan Analisa

Pada pengolahan data well untuk analisa petrofisika dibutuhkan nilai-nilai log Gamma Ray, SP, Densitas, Neutron Porosity (NPHI), LLD dan LLS. Data log digunakan untuk menentukan lokasi reservoir, kandungan fluida dalam reservoir, dan menentukan litologi formasi. Data sumur yang didapat merupakan sumur vertikal. Namun terdapat permasalahan dalam data sumur yang kami dapat, yaitu tidak terdapatnya data tops, mud resistivity dan temperature sehingga perhitungan koreksi tidak akan benar benar mendekati nilai sebenarnya.

\begin{tabular}{|c|c|c|c|c|c|c|}
\hline $\begin{array}{c}\text { Nama } \\
\text { Sumur }\end{array}$ & GR & SP & Densitas & Neutron & LLD & LLS \\
\hline TG-1 & $\mathbf{v}$ & $\mathbf{v}$ & $\mathbf{v}$ & & $\mathbf{v}$ & $\mathbf{v}$ \\
\hline
\end{tabular}

TG-2 \begin{tabular}{l|l|l}
$\mathrm{v}$ & $\mathrm{v}$ & $\mathrm{v}$
\end{tabular}

Kemudian dilakukan perhitungan koreksi data log, penentuan Vshale, porositas, dan saturasi air dan melakukan interpretasi dasar sehingga didapat bentuk litologi log dasar untuk acuan dalam penentuan fasiesnya.

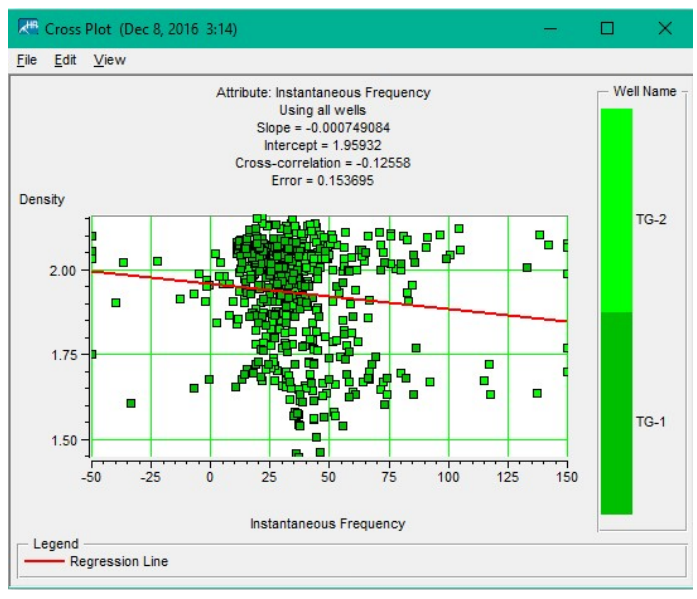

Gambar 9 Crossplot Well TG-1 dengan TG-2 menggunakan atribut Instantaneous Frequency

Pada pengolahan data seismic dilakukan dua tahapan dasar yaitu picking horizon dan picking fault. Lalu dilakukan tahapan lanjutan yaitu pemodelan reservoir, pada pemodelan reservoir dilakukan banyak tahapan mulai dari pembuatan surface, layering, input well, pembuatan model 2D dan 3D. Data yang digunakan pada tahapan ini ialah data Depth Migration yang merupakan data dengan resolusi kedalaman dan bukan lagi data seismic dengan resolusi waktu.

Pada penelitian ini data yang diinterpretasi sebagai horizon ialah top globigerina, sandy globigerina, gas water contact dan wonocolo. Hal tersebut merupakan hasil dari kolaborasi data litostratigrafi dan data well.

Dalam melakukan picking horizon perlu ada controlling dari masing masing inline dan crossline yang dimiliki data seismic. Horizon yang dipicking dari awal lintasan yang biasanya merupakan tempat yang berpotongan dengan hasil data well. Dan data picking yang telah diambil pada inline harus sesuai dan memotong data picking horizon tersebut pada daerah crossline. Kesesuaian pengambilan data di 
inline dan crossline menunjukkan kekonsistenan dalam picking horizon.

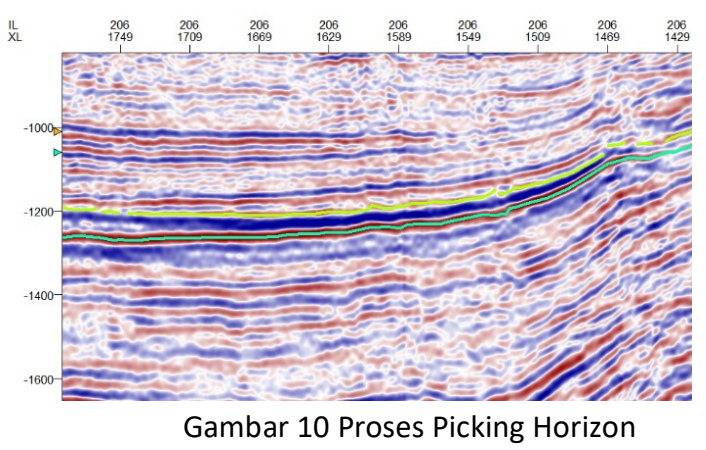

Pada pembuatan model lapisan, dilakukan pembuatan polygon untuk daerah yang ingin dibuat modelnya, lalu dilakukan input data picking horizon dan nilai luasan grid yan diinginkan. Hal ini dilakukan sebanyak jumlah horizon yang telah dipicking.

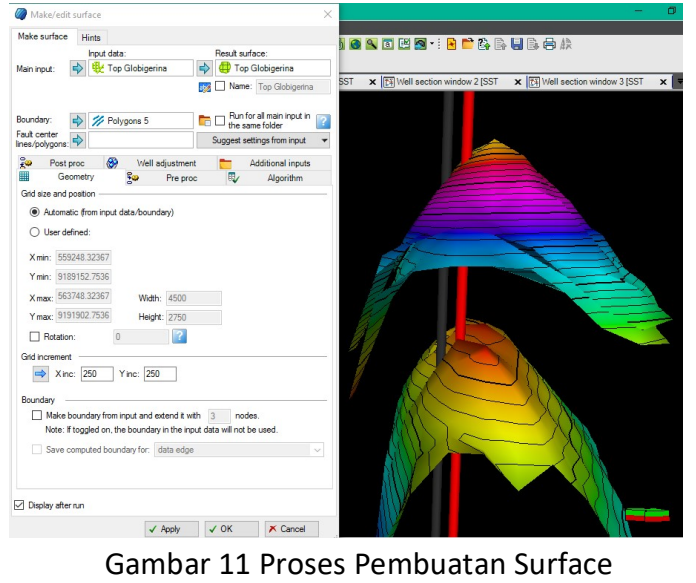

Pada korelasi data well dengan data seismic dilakukan input data well dan input data surface pada window well correlation dan dilakukan pengepasan hasil surface dengan data well seperti pada gambar berikut.

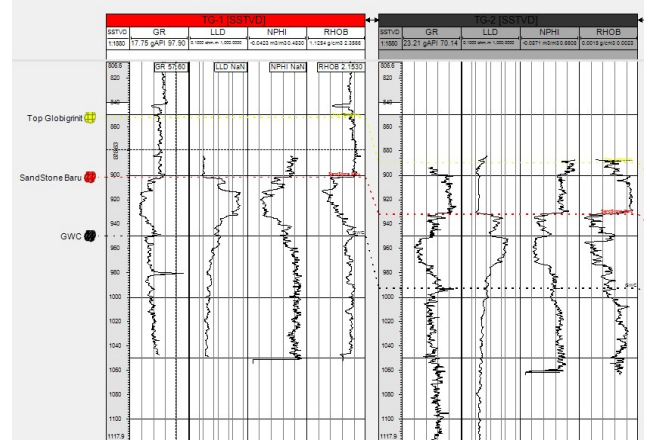

Gambar 12 Proses Penentuan Well Top
Pada griding model dilakukan pemodelan menggunakan input data surface dari hasil well correlation. Lalu dilakukan input surface mulai dari lapisan teratas hingga terbawah dan dilakukan griding sesuai dengan hasil kita picking horizon, semakin tipis kita melakukan picking horizon maka kita bisa membuat model dengan grid kecil yang menghasilkan resolusi lebih detail.

Setelah dilakukan pembuatan grid, maka bisa ditampilkan bentuk model 2D yang ada. Untuk mendapatkan model 3D maka perlu memasukkan batas-batas yang ada baik secara vertical maupun horizontal $(x, y, z)$. Kemudian perlu diketahui batas batas pucuk dari hasil surface yang telah dibuat sehingga bentukan 3D bisa di dapat.
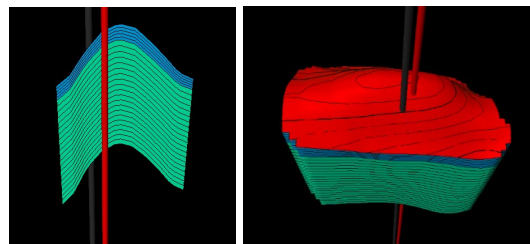

Gambar 13 Hasil Gridding Model 2D dan Model 3D

Fluid contact digunakan untuk mengetahui batas kontak antar fluida, nilai fluid contact didapat dari hasil interpretasi well dan dari hasil fluid contact yang ada pada well dilakukan picking horizon untuk mengetahui sebaran dari batas fluida tersebut. Berikut ini merupakan hasil fluid contact yang telah dilakukan sehingga model reservoir bisa ditampilkan.

Pada interpretasi fasies, nilai API log Gamma Ray sangat kecil, menurut Glover, 2007 hal ini mengindikasikan keberadaan karbonat lebih tepatnya limestone. Dengan perbandingan data Gamma Ray dan Stratigrafi maka dipastikan bahwa data well merupakan data full karbonat. Maka dari itu digunakan pembagian kelompok jenis batuan limestone, dari data pembimbing menyatakan bahwa log pada well hanya berada di reservoir limestone globigrinit, sehingga perlu adanya klasifikasi batuan reservoir globigrinit tersebut berdasarkan nilai densitas dan p-wave (sonic) nya yang didapat dari data log. 


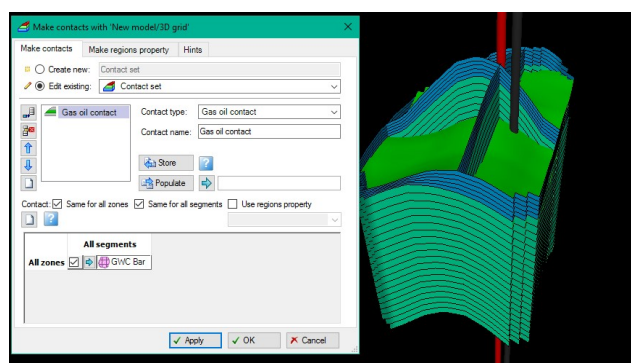

Gambar 14 Proses Pembuatan Kontak Fluida pada Model

Pada tahapan facies modelling dilakukan pemodelan dari hasil data atribut well seismic dan data klasifikasi well log facies. Kemudian dilakukan crossplot antara data well terhadap data seismik. Sehingga didapat dua control untuk menyebarkan keberadaan fasies pada model. Dalam pembuatan model dilakukan input grid yang telah dibuat sebelumnya untuk dimasukkan properti-properti dari data well maupun data atribut.

\section{HASIL DAN PEMBAHASAN}

\section{Analisis Rekahan}

Menurut penelitian yang sudah dilakukan menggunakan metode klasifikasi fasies, griding dan kontrol model maka didapat pembagian kelompok jenis batuan dan bentukan model fasies secara 3D.

Pembagian jenis batuan dari data geologi reservoir yang ada, maka pada reservoir batuan globigrinit tersebut dibagi lagi klasifikasinya menjadi 4 berdasarkan nilai densitas dan p-wave (sonic) nya yang didapat dari data log seperti pada gambar dibawah.

\section{- Compact Globigrinit}

Yaitu merupakan batuan globigrinit yang kompak dan masih utuh, sehingga batuan tersebut memiliki pori yang sangat kecil dan merupakan reservoir yang buruk walaupun menurut Glover densitas dari batuan ini masih dianggap sebagai reservoir.

\section{- Shaly Globigrinit}

Yaitu merupakan batuan globigrinit yang tidak kompak namun rekahan yang ada terisi oleh shale sehingga walaupun batuan ini memiliki densitas yang besar ia tetap tidak kompak dan masih memiliki pori. Hal ini ditunjukkan oleh besarnya nilai p-wave (sonic) nya. Karena menurut Glover, nilai sonic yang tinggi (di atas $100 \mathrm{us} / \mathrm{ft}$ ) merupakan shale dan densitas $2.5 \mathrm{gr} / \mathrm{cm}^{3}$ merupakan limestone solid dan dibawah itu menunjukkan limestone berpori. Sehingga pada pengelompokkan shaly globigrinit ini menunjukkan keberadaan limestone globigrinit yang memiliki pori dan terisi oleh shale.

- Sandy Globigrinit

Sandy globigrinit merupakan limestone globigerina yang memiliki pori dan terisi oleh batuan pasir. Batuan pasir disini bukanlah batu pasir kuarsa yang memiliki densitas yang tinggi, melainkan merupakan batuan pasir hasil pecahan dari batuan globigerina tersebut dan mengisi poripori yang ada. Batuan sandy globigrinit merupakan batuan yang sangat cocok sebagai tempat reservoir karena memiliki pori yang besar.

\section{- Super Sandy Globigrinit}

Super sandy globigrinit adalah limestone globigerina yang memiliki densitas yang sangat kecil, $\mathrm{p}$-wave yang kecil dan porositas yang sangat besar. Ini menunjukkan bahwa batuan ini adalah batuan limestone berpori yang porinya sangat sedikit terisi matriks ataupun terisi dengan butirbutir yang besar sehingga masih menyisakan ruang porous yang besar untuk diisi oleh fluida.

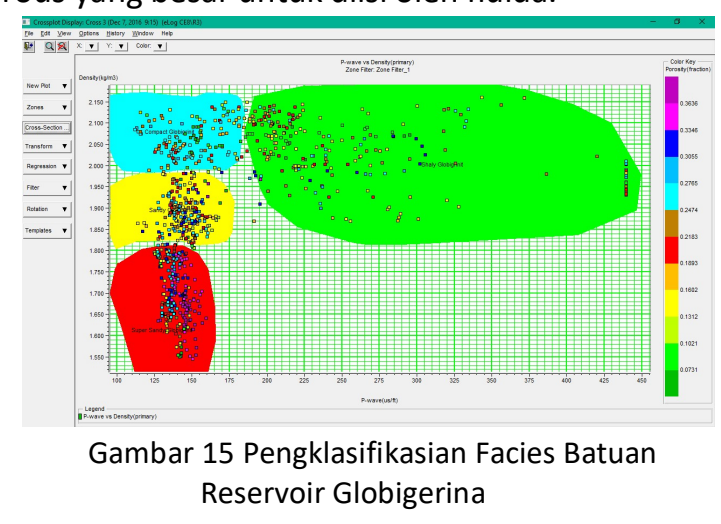

Pada penggabungan hasil gridding model dengan data well didapat empat bentukan model yang merupakan hasil pesebaran data porositas, densitas, sonic, dan fasies. Dari keempat model tersebut dapat dilihat bahwa porositas terbaik dengan rentang nilai 0.2 - 0.3 berada pada daerah top reservoir yang ditunjukkan oleh zona berwarna merah.

Sedangkan densitas terrendah didapat pada daerah top reservoir juga. Log densitas mengindikasikan keterdapatan porositas dan untuk mengidentifikasi jenis batuan. Dan ini ditunjukkan 
oleh zona berwarna ungu. Namun terdapat beberapa kesalahan yang dikarenakan oleh ketidaksesuaian penggunaan atribut dan nilai korelasi dalam menyebarkan nilai densitas sehingga didapat densitas dengan nilai 0 .

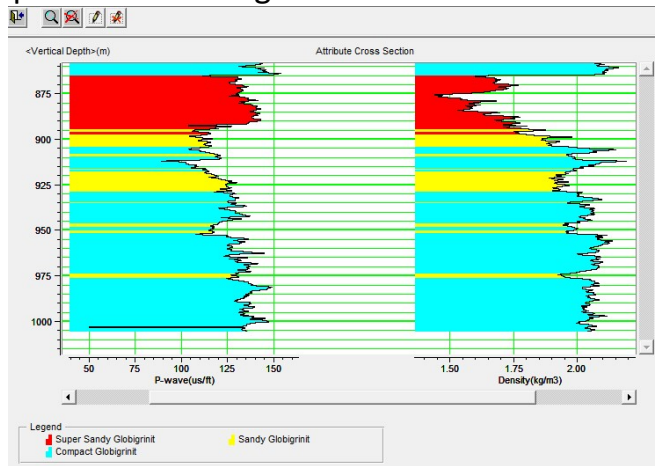

Gambar 16 Hasil Log Densitasi dan Sonic dari pengklasifikasian Facies Batuan Reservoir Pada Well TG-1

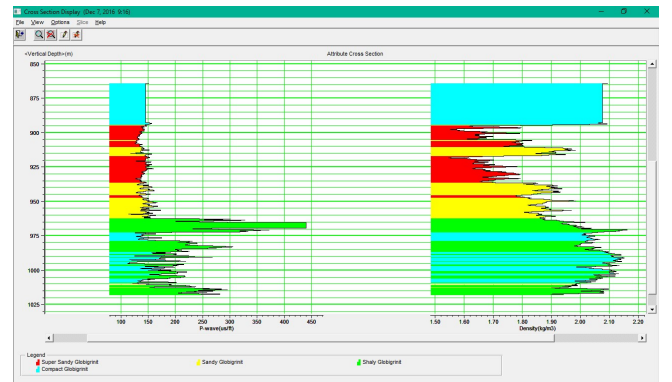

Gambar 17 Hasil Log Densitas dan Sonic dari pengklasifikasian Facies Batuan Reservoir Pada WellTG-2

Nilai sonic juga menunjukkan jenis porositas dan untuk mengidentifikasi jenis batuan. Log sonic biasa dikombinasikan dengan log densitas untuk mendapatkan nilai porositas dan biasa dikorelasikan dengan log SP, densitas, GR, resistivitas untuk mendapatkan jenis batuan yang ada. Semakin kecil nilai sonic ditunjukkan oleh warna ungu yang menunjukkan daerah tersebut merupakan daerah reservoir. Dan merah menunjukkan daerah permeable.

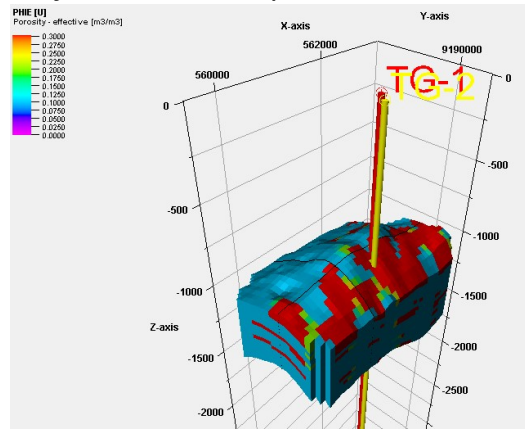

Gambar 18 Model Porosity 3D
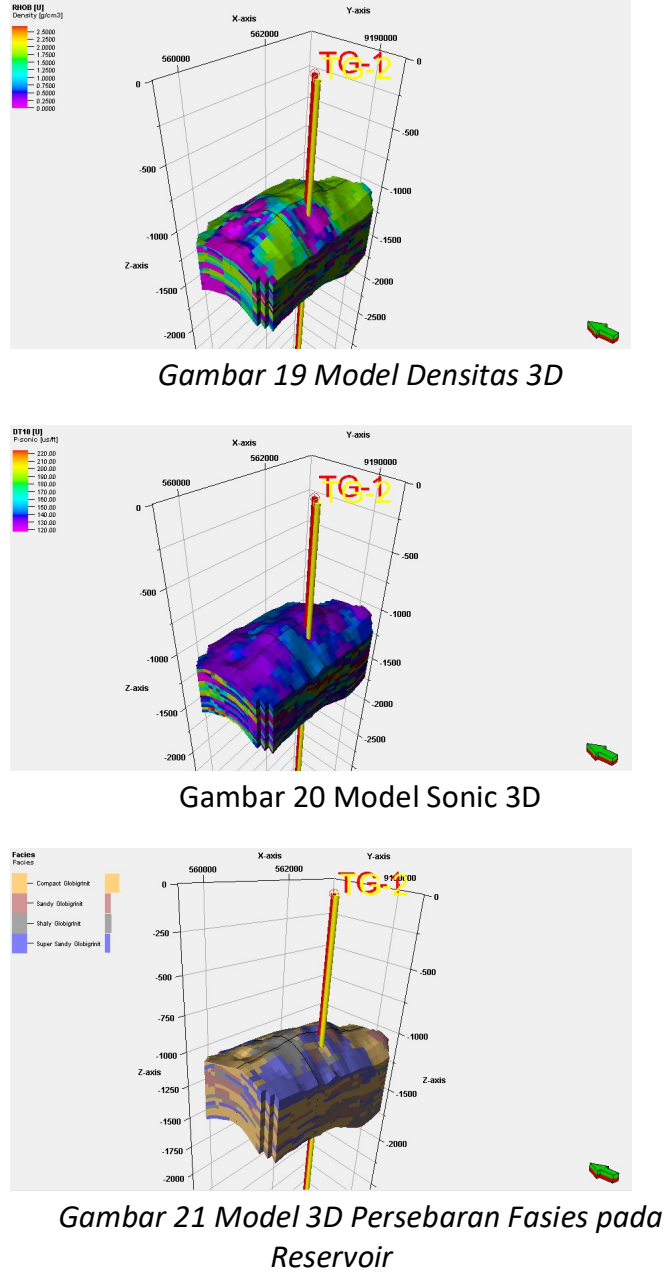

Model fasies 3D ini merupakan hasil dari interpretasi data pengelompokkan log densitas dan sonic yang telah dipicking kemudian dikorelasikan dengan nilai porositas serta atribut Instantaneous Frequency. Diambil nya data porositas sebagai korelasi dikarenakan data log fasies sendiri merupakan hasil dari data densitas dan sonic, sehingga diperlukan pembanding lain sebagai kontrol.

Dari data fasies ini dapat dianalisa bahwa model reservoir globigerina limestone ini memiliki bentukan massif globigrinit yang mana kebanyakan dari fasies Super Sandy Globigrinit berada di top model yang merupakan reservoir terbaik yang berisi gas biogenic. Daerah top model lainnya juga menunjukkan bentukan compact globigrinit dan shaly globigrinit yang mana merupakan lapisan permeable namun masih memiliki pori. Hal ini dikarenakan bentukan dari limestone sendiri yang 
mudah memiliki rongga yang dapat diasumsikan dari nilai sonic dan densitas yang rendah.

\section{PENUTUP}

\section{Kesimpulan}

Kesimpulan yang didapat dari penelitian ini antara lain.

1. Keseluruhan badan reservoir adalah batuan limestone karena dari data log Gamma Ray menunjukkan nilai API yang sangat kecil yaitu dalam rentang 20-60 API.

2. Didapat 4 pengklasifikasian data facies dari hasil crossplot log densitas dan sonic yang terbagi menjadi Super Sandy Globigrinit, Sandy Globigrinit, Compact Globigrinit dan Shaly Globigrinit.

3. Model Facies 3D hanya menunjukkan korelasi data well dengan satu atribut seismik saja dan tanpa adanya kontrol dari patahan yang telah di pick.

\section{Saran}

Saran yang dapat diberikan berdasarkan hasil dan kesimpulan untuk membangun hipotesahipotesa selanjutnya antara lain.

1. Perlu adanya penelitian-penelitian serupa dengan konsentrasi luasan yang lebih besar sehingga bisa dilihat hasil persebaran fasies secara regional.

2. Untuk mendapatkan hasil yang lebih baik dan akurat, bisa dilakukan analisa neural network dan pengkorelasian dengan data atribut seismik lainnya.

3. Nilai kebenaran persebaran fasies bisa ditingkatkan dengan adanya jumlah data well yang lebih banyak sebagai kontrol kuantitatif dan kualitatif.

\section{DAFTAR PUSTAKA}

Glover, Paul. 2007. Petrophysics MSc course notes.

Harsono, Adi. 1997. Evaluasi Formasi dan Aplikasi Log. Jakarta : Schlumberger Oilfield Service.
Rice, Dudley D., Claypool, George E. 1981. Generation, Accumulation and Resource Potential of Biogenic Gas. American Assosiation of Petroleum Geologist Bulletin.

Satyana, Awang Harun dan Margaretha E.M. Purwaningsih. 2003. Geochemistry of The East Java Basin: New Observations on Oil Grouping, Genetic Gas Types and Trends of Hydrocarbon Habitats. Indonesian Petroleum Association.

Schlumberger, 1989, Log Interpretation Principles/Aplication, Schlumberger Educational Services, Texas.

Sukmono, S. 2007. Fundamentals of Seismic Interpretation. Geophysical Engineering, Bandung Institute of Technology, Bandung.

Susilohadi. (1995). Late Tertiary and Quaternary Geology of The East Java Basin, Indonesia. Australia: The University of Wolonggong.

Walker, R. G., 2006. Facies Models Revisited in Posamentier, H. W., and R. G., Walker, Facies Models Revisited, Society for Sedimentary Geology (SEPM), p. 375.

White, L. 1991. Adverb placement in second language acquisition: Some effects of positive and negative evidence in the classroom. Second Language Research, 7, 133161

Zain, Riki Pahlevi. 2012. Analisis Petrofisika Dan Perhitungan Cadangan Minyak Pada Lapangan "Bear" Cekungan Sumatra Tengah. Tugas Akhir Program Sarjana, Universitas Indonesia. 